Seminário de Pesquisa

Programa de Pós-Graduação

Design FAU USP

\title{
Letreiramentos da Liberdade: um método para identificação de caracteres em inscrições japonesas no espaço urbano
}

\author{
Eduardo Araújo de Ávila, Priscila Lena Farias
}

\author{
Liberdade; escrita japonesa; caracteres; procedimentos \\ metodológicos; letreiramento
}

Este estudo examina métodos e técnicas para seleção, tratamento e análise de dados referentes a parte do corpus de uma pesquisa sobre a caracterização do bairro oriental da Liberdade em São Paulo, composto por inscrições contendo caracteres dos sistemas de escrita japoneses kana e kanji encontradas no espaço público. A partir do procedimento de pesquisa documental, foram consideradas fontes de dados primários fotografias registradas no local a partir da década de 1940, encontradas em acervos digitais de acesso gratuito pertencentes a instituições culturais e museus. As pesquisas

Curso

Doutorado

\section{Linha de Pesquisa}

Teoria e História do Design

\section{Eduardo Araújo de Ávila}

Eduardo Araújo de Ávila

Doutorando em Design pela FAU

USP, possui mestrado em Arte e

Cultura Visual e graduação em

Design Gráfico pela FAV UFG.

Desenvolve atividades de ensino e pesquisa em artes visuais, design visual, e design educacional.

e-mail: eduavila@usp.br

Lattes: http://lattes.cnpq.

br/4846236483936266

Orcid: https://orcid.org/0000-

0003-1208-1760

\section{Priscila Lena Farias}

Priscila Lena Farias Professora

Associada e coordenadora do

LabVisual - Laboratório de

Pesquisa em Design Visual na FAU

USP. Autora de diversos artigos e

livros sobre tipografia, semiótica e design. Seus interesses atuais de pesquisa são história da tipografia, e letreiramento no espaço público.

e-mail: prifarias@usp.br

Lattes: http://lattes.cnpq.

br/7204930940034076

Orcid: http://orcid.org/0000-

0002-2540-770X de D'Elboux (2013), Finizola (2015) e Farias (2016) serviram de referência quanto aos procedimentos metodológicos. Como parte do processo de análise gráfica, trechos das imagens contendo inscrições foram recortados e receberam o tratamento necessário para a observação de aspectos estéticos e morfológicos. Diferentes métodos para analisar as amostras resultantes foram considerados, tais como descrever os elementos das inscrições e o traçado dos caracteres; e categorizar as inscrições de acordo com as definições (tipografia arquitetônica, artística, comercial, entre outras) que correspondem à análise da paisagem tipográfica. Entretanto, durante o tratamento de dados, foram encontradas limitações técnicas que dificultavam a compreensão de algumas inscrições, decorrentes da baixa qualidade de resolução das imagens. A solução encontrada foi realizar busca por anúncios publicados pelas empresas responsáveis pelas inscrições em jornais do mesmo período. Desta forma, os caracteres presentes em 28 das 69 inscrições que fazem parte do corpus puderam ser identificados. 


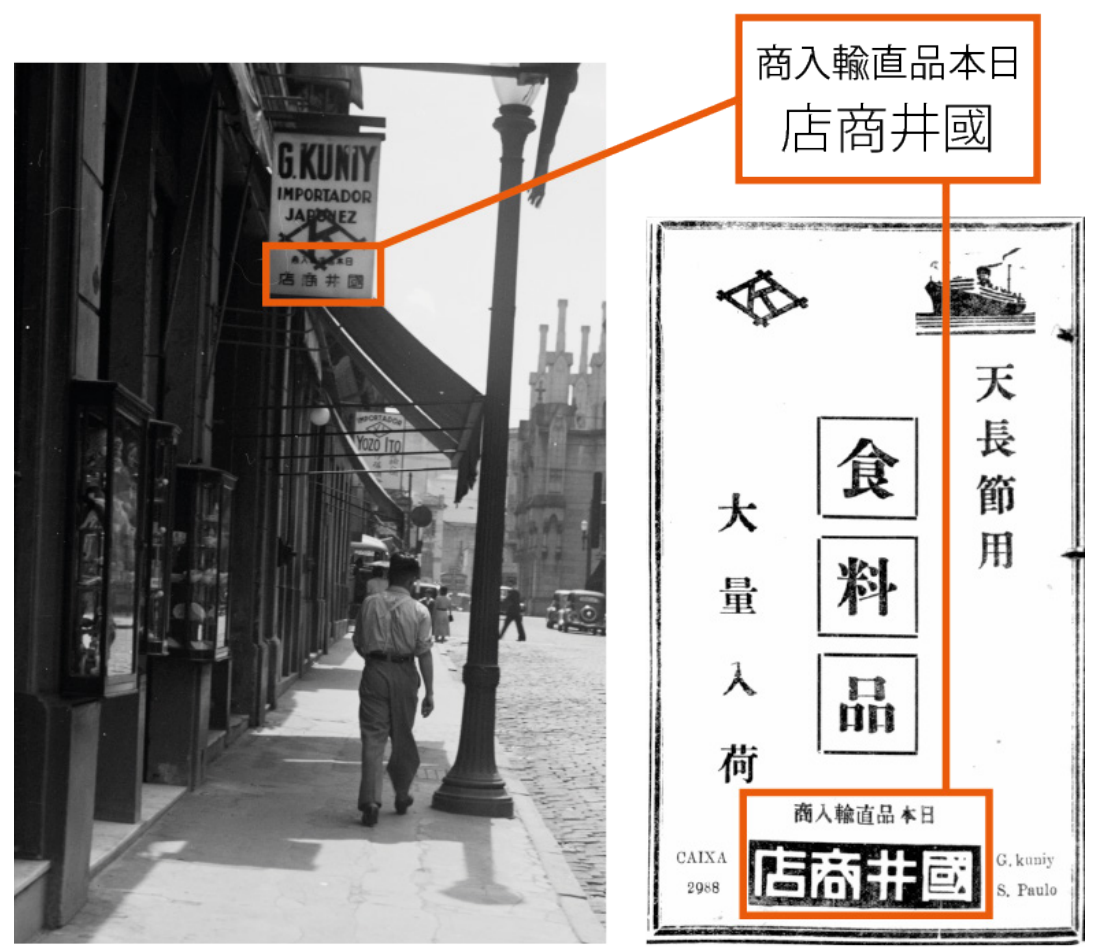

Fig. 1 Comparação dos caracteres japoneses no letreiro e no anúncio de jornal da empresa G. Kuniy Shōten. | Comparison of the Japanese characters in G. Kuniy Shōten sign and newspaper ad.

Course

Doctoral

\section{Line of Research}

Design Theory and History

\section{Eduardo Araújo de Ávila}

PhD student in Design at FAU USP, has a Master's degree in Art and Visual Culture and a Bachelor's degree in Graphic Design from FAV UFG. He develops teaching and research activities in visual arts, visual design, and educational design.

e-mail: eduavila@usp.br

Lattes: http://lattes.cnpq. $\mathrm{br} / 4846236483936266$

Orcid: https://orcid.org/00000003-1208-1760

\section{Priscila Lena Farias}

Associate Professor and coordinator of LabVisual - the Visual Design Research Lab at FAU USP. Author of several articles and books on typography, semiotics and design. Her current research interests are the history of typography, and lettering in the public space.

e-mail: prifarias@usp.br

Lattes: http://lattes.cnpq. br/7204930940034076

Orcid: http://orcid.org/00000002-2540-770X

\section{Letterings of Liberdade: a method for identifying characters in Japanese inscriptions in the urban space}

\section{Eduardo Araújo de Ávila, Priscila Lena Farias}

\section{Liberdade; Japanese writing; characters; methodological procedures; lettering}

This study examines methods and techniques for the selection, treatment and analysis of data relative to part of the corpus of a research on the characterization of the Japanese district of Liberdade in São Paulo, consisting of inscriptions containing characters from Japanese writing systems kana and kanji, found in the public space. From documentary research procedures, photographs registered in the locality from the 1940s onwards, found in free access digital archives belonging to cultural institutions and museums, were considered as primary data sources. Investigations conducted by D'Elboux (2013), Finizola (2015) and Farias (2016) served as a reference for methodological procedures. As part of the graphic analysis process, parts of the images containing inscriptions were cropped and received the necessary treatment for the observation of aesthetic and morphological aspects. Different methods were considered for analyzing the resulting samples, such as the description of the inscription elements and characters strokes; and categorization of inscriptions according to the definitions 
(architectonic, artistic, commercial typography, among others) that correspond to the analysis of typographic landscapes. However, during data treatment, technical limitations that hindered the understanding of some inscriptions, arising from the low resolution of the images, were found. The solution found was to search for advertisements published by the companies responsible for the inscriptions in newspapers of the same period. Thus, characters present in 28 of the 69 inscriptions that are part of the corpus could be identified.

\section{Referências | References}

D'ELBOUX, J. R. 2013. Tipografia como elemento arquitetônico no Art Déco paulistano: uma investigação acerca do papel da tipografia como elemento ornamental e comunicativo na arquitetura da cidade de São Paulo entre os anos de 1928 a 1954. Dissertação de mestrado, FAU USP, São Paulo.

FARIAS, P. L. 2016. Estudos sobre tipografia: letras, memória gráfica e paisagens tipográficas. Tese de livre-docência, FAU USP, São Paulo.

FINIZOLA, F. 2015. A tradição do letreiramento popular em Pernambuco: uma investigação acerca de suas origens, forma e prática. Tese de doutorado, CAC UFPE, Recife. 